\author{
Paweł Levchuk \\ Institute of Slavic Studies, Polish Academy of Sciences, Warsaw, Poland \\ pavlo.levchuk@ispan.waw.pl
}

\title{
Ukrainian Language in Polish Public Space
}

\begin{abstract}
The article deals with examples of the use of Ukrainian in Polish public space. Ukrainians are the largest immigrant group in Poland, with an estimated 2 million people. Most of them speak Polish at an elementary level. This situation has led to the appearance in Polish public space of Ukrainian-language advertising of banks, mobile operators, cinemas, various services, information about the COVID-19 pandemic, and so on. Although formally the Ukrainian language remains exclusively the language of a national minority, its use indicates an increasing need for Ukrainianlanguage advertising in various environments.
\end{abstract}

Keywords: Ukrainian language in Poland; advertising; language policy

\section{Background}

Since 2014, Poland has been experiencing an ever-increasing wave of Ukrainian immigration. Pavlo Levchuk has called it the fifth wave of migration of Ukrainians to Poland, which has exceeded the previous four waves in terms of volume and is still continuing (Levchuk, 2020, p. 54). Ukrainians migrate to the West in search of better-paid work. The first country on this road is Poland, which is need of a workforce that can contribute not only to the economic growth of specific employers, but also to the whole country by paying taxes. To obtain a visa or work permit in Poland, knowledge of the state language (Polish) is not required. Knowledge of Polish is only a requirement for a European Union residency card, a certificate of permanent residence or Polish citizenship. These rules have allowed Poland to accept approximately 2 million immigrants from Ukraine alone (Levchuk, 2020; Pawłowski, 2019c, p. 26), who either temporarily or permanently live and work in Poland.

After World War II, Russian, the official language of the Soviet Union, played an important role in Poland. It was widely believed that everyone from the former USSR could speak Russian to some extent. Hence, people living to the east of Poland were referred to in Polish as 'Ruskie' (Russians). Poland's accession to the EU shifted the line of thinking to the West, and the Russian language lost its position, becoming less and less of a popular choice of language for learners. In 1987 as many as $83 \%$ of school graduates took the final exam in foreign languages in Russian. In 1998 this proportion had fallen to $24 \%$, in $2006,5.3 \%$. In 2018, a mere $1.7 \%$ of graduates took a final exam in Russian (Pawłowska, 2018, pp. 111-112; Pawłowski, 2019a, p. 165; Wróblewska-Pawlak \& Strachanowska, 2000, pp. 102-104). Not until after 2014, following the annexation of Crimea and the occupation of the Donbas region, did Poland begin to seriously consider the introduction of Ukrainian into the advertising space, as Ukrainians were the largest group of foreigners, and were beginning to dominate Polish universities (Levchuk, 2020, p. 57), were obtaining work permits (Levchuk, 2020, pp. 58-60), and were trying to confirm their level of proficiency in the Polish language (Miodunka, 2016, p. 255), thus opening the way to a long-term stay in Poland. It is 
worth mentioning that the language situation in Ukraine has also changed (Demska \& Levchuk, 2020; Levchuk, 2020, pp. 29-39), which in turn has had an impact on the situation of the Ukrainian language in Poland.

\section{The State of Research and Methodology}

Research on the Linguistic Landscape focuses primarily on how language is manifested in public spaces (Gorter, 2006, pp. 1-6). Theoretical issues related to the study of the language landscape have been addressed in many works (Backhaus, 2007; Gorter, 2013, pp. 190-212; Shohamy, 2012, pp. 538-551). The first investigations in this area identified two basic functions of inscriptions that appear in public space: communicative and symbolic.

In this article, special attention is paid to the communicative function, because it consists of clear language which becomes a determining factor in choosing a mobile operator or a bank in which to open an account, pay deposits into, or take a loan from etc. for a large group of immigrants.

In the international professional literature, the subject of research on the language landscape is gradually expanding, and consequently the concept itself is constantly gaining new interpretations. Today it is a part of the language of documents, official forms, business cards, and the labelling of goods (Backhaus, 2007; Laihonen, 2015; Shohamy \& Gorter, 2009; Shohamy \& Waksman, 2009).

Ukrainian is also becoming an object of research. Worth mentioning are works on the language landscape in Ukraine (Bever, 2010; Demska, 2019; Pavlenko, 2009, 2010) and the situation of Ukrainian in the context of multilingualism and trilingualism (Levchuk, 2019, 2020; Redkva, 2020). Studies have been conducted on the presence of Polish and Ukrainian in other countries, such as on the banknotes of the Czechoslovak Republic in the interwar period (Berehsasi et al., 2020).

Adam Pawłowski (Pawłowski, 2019a, 2019b, 2019c) was the first Polish linguist to pay attention to the functioning of Ukrainian Poland. Describing the language landscape of Poland, Pawłowksi draws attention to the special functioning of Ukrainian in the Polish language landscape, as the language of the largest group of immigrants to Poland. Although legally Ukrainian remains the language of a national minority, in reality it can be found throughout the whole country, not only in the homes and communities of the minority, as is the case with other languages, as illustrated by Helena Krasowska (Krasowska, 2020, pp. 30-31).

The purpose of this article is to highlight the presence of the Ukrainian language in Polish public discourse, showing the various areas where the Ukrainian language is present.

\section{Results}

In 2018, the presence of foreign languages on Polish websites was as follows (cf. Tab. 1):

Table 1. Presence of foreign languages on the websites of Polish institutions and companies. Elaboration by Adam Pawłowski (2019a, p. 177, 2019b, p. 16).

\begin{tabular}{|l|r|r|r|r|r|}
\cline { 2 - 6 } \multicolumn{1}{c|}{} & English & Russian & Ukrainian & Chinese & German \\
\hline Universities & $96 \%$ & $29 \%$ & $18 \%$ & $13 \%$ & $4 \%$ \\
\hline Banks & $61 \%$ & $6 \%$ & $28 \%$ & - & - \\
\hline Public transport in cities & $100 \%$ & $31 \%$ & $12 \%$ & - & $92 \%$ \\
\hline Voivodeship offices & $75 \%$ & $63 \%$ & $31 \%$ & - & $31 \%$ \\
\hline Insurance companies & $26 \%$ & $7 \%$ & $7 \%$ & $7 \%$ & $7 \%$ \\
\hline
\end{tabular}


If we compare the frequency of use of foreign languages, we can safely conclude that Ukrainian is used much more often in the Polish Internet space than Chinese. The position of Ukrainian compared with German can also be considered better, except for the case of public transport in cities, where German retains its position due to the large number of German-speaking tourists visiting Poland. If we compare the frequency of use of Russian and Ukrainian, Russian has a greater influence than Ukrainian. Ukrainian has gained a higher position in the banking sector, as the ability to communicate in Ukrainian gives banks reliability in the eyes of potential immigrant clients and allows banks to serve more user accounts. Insurance companies use Russian, Ukrainian, Chinese and German equally, so the positions here remain the same. The strongest position of Russian is on the portals of the bodies that legalize the immigrant and work status of foreigners, where Russian remains the second language after English. In public transport and education, Ukrainian is already catching up with Russian, but the long-standing stereotype of a common Russian language stands in the way of this process.

It is worth noting that advertising in Ukrainian is only the first step, as companies also have staff who are ready to serve customers in Ukrainian. The use of Ukrainian in various companies makes it possible to solve urgent issues without knowing Polish. In large cities (for example Wroclaw and Lodz) there are commissioners for Ukrainians or commissioners for foreigners, who are usually Ukrainians themselves (Walbrzych).

\subsection{Education}

The educational sphere, due to the presence of pupils and students from Ukraine, has begun to use Ukrainian, often for advertising purposes in order to encourage more potential students to choose their educational institution.

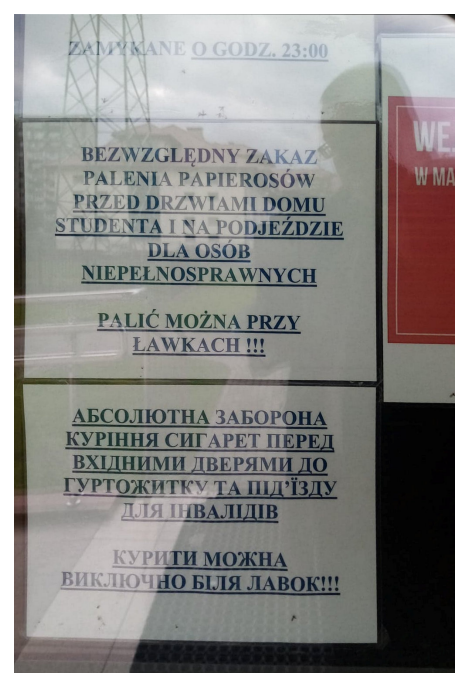

Figure 1.

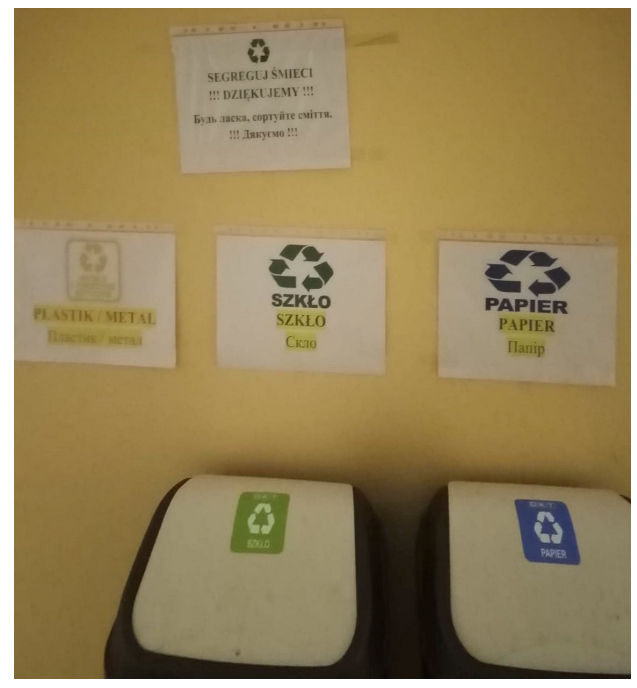

Figure 2.

In Polish schools, an intercultural assistant who speaks the language of foreign pupils (in the case of children from Ukraine, Ukrainian or sometimes Russian), may be hired to help integration during the first year of a pupil's education at the school. The assistant also helps parents communicate with teachers. You can find information in Ukrainian for foreigners on the websites of Polish schools ${ }^{1}$ cf. Figure 1 above. Some schools are beginning to introduce Ukrainian Language, Culture and History as a subject in their curriculums. However, the issue of financing such lessons

\footnotetext{
${ }^{1}$ Information for foreigners in Ukrainian. Website of the Secondary School Complex No. 18 in Krakow http://zso18.krakow.pl
} 
by Ukrainian diplomatic missions or the local budgets of Polish cities hinders their development. There is also a lack of methods for teaching Ukrainian as a second language to Ukrainian children in Poland, and subsequent generations of migrants born in Poland may not have a written code.

Polish universities often do not only create advertisements in Ukrainian, but also hire immigrants from Ukraine to explain the rules of admission and to help new Ukrainian students adapt to their new environment. Even the largest and most prestigious public universities, which are in high demand among Polish students, also offer information in Ukrainian. The Jagiellonian University in Krakow even offers Ukrainian language teaching as part of cultural studies. ${ }^{2}$

Ukrainian is also present in university dormitories, where most foreign students usually live (photos are by the author unless stated otherwise; Przemyśl, cf. Figure 2 on p. 3).

\subsection{Information and Restrictions Related to COVID-19}

The coronavirus pandemic has also led to the appearance of more Ukrainian in the public sphere. Polish authorities created the application Kwarantanna domowa to monitor people in quarantine or isolation. When installing the application on a smartphone, it is possible to select Ukrainian as the application language.

Information for passengers on Warsaw public transport can also be seen in Ukrainian, cf. Figure 3 below.

In the regions close to the Polish-Ukrainian border, one can find information about COVID-19 testing centres, cf. Figure 4 below.

Even whole information notices have started to be published in Ukrainian. One of them is shown in the photo below, taken in Przemyśl, cf. Figure 5 below.

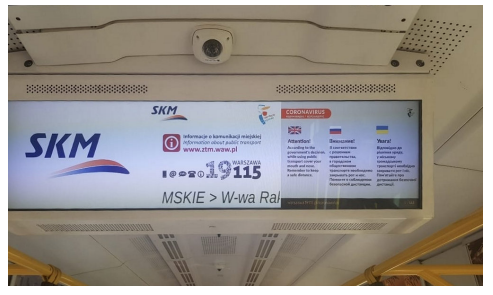

Figure 3. Photo by Oksana Fain. Warsaw.

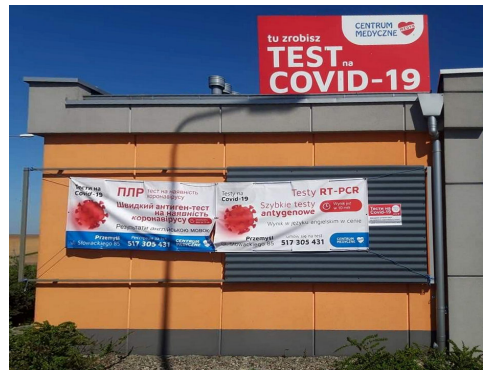

Figure 4. Photo taken in the suburbs of Przemyśl.

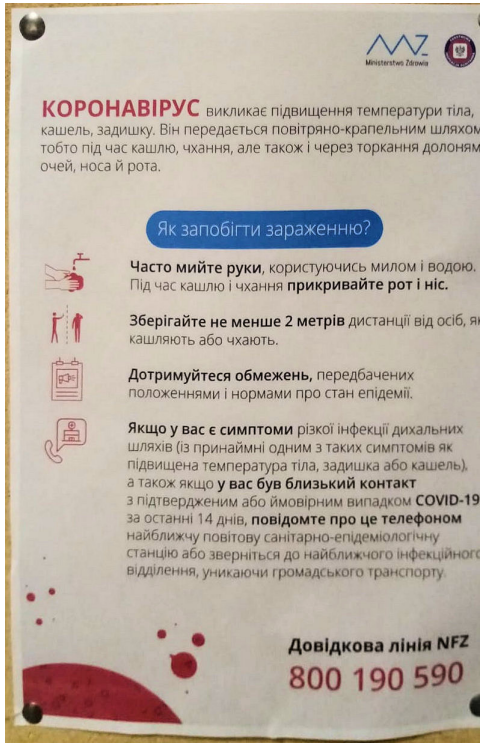

Figure 5 .

\subsection{Religious Communities}

An important place where Ukrainian can be found is the Greek Catholic Church. The Ukrainian language is always present in this denomination and Poland is no exception. Other religious

\footnotetext{
2 Jagiellonian University https://wsmip.uj.edu.pl/uk_UA/candidates/admissions; Uniwersytet Marii Curie-Skłodowskiej https://www.umcs.pl/uk/
} 
communities also use Ukrainian, both for the purposes of information and the evangelization of potential worshippers. An example from Krakow is the Jehovah's Witness community, cf. Figures 6,7 .

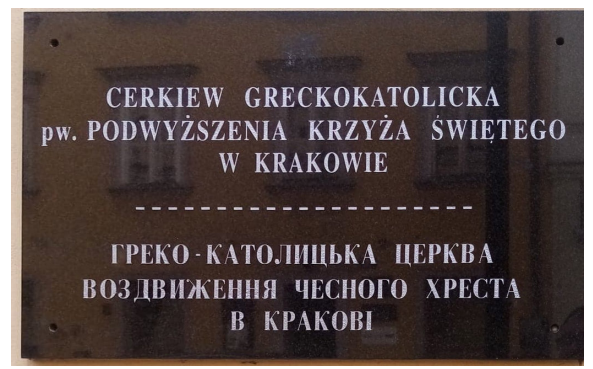

Figure 6.

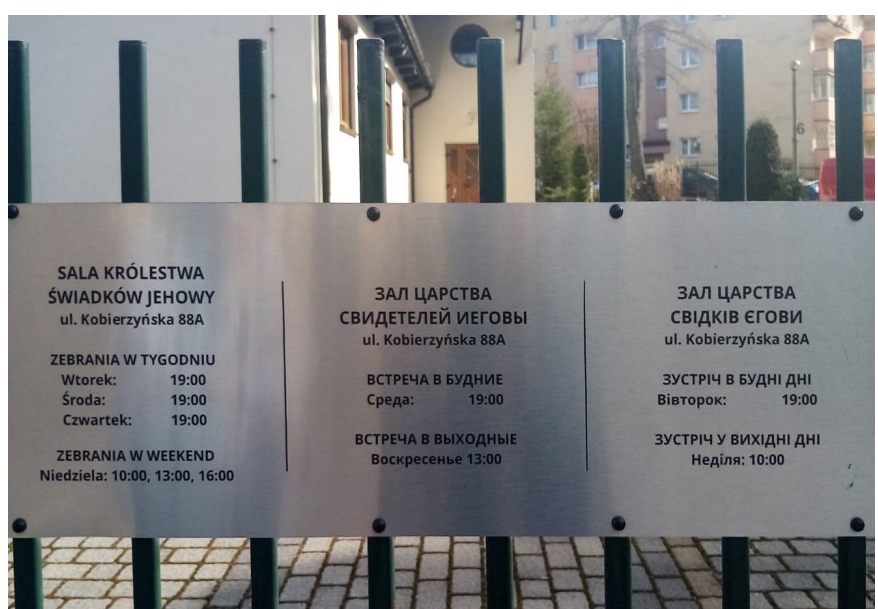

Figure 7.

\subsection{Cinemas and Museums}

An interesting example of the use of Ukrainian in cinema advertising can be seen in Wroclaw (photo to the right by Elena Ratzko). The cinema is displaying the following advertising - "Movie hits in your language in your city". In doing so, it is attempting to show Ukrainians living in Wroclaw that it is their city, thus creating a sense of multiculturalism (cf. Levchuk, 2020, p. 93). Films shown with Ukrainian subtitles can be found in Wroclaw, Krakow, Warsaw and Lublin.

Additionally, some museums are starting to offer audio guides or tours in Ukrainian. Examples of audio guides are the Czartoryskich Museum in Krakow (U Krakivs'komu muzeï kniaziv Chartoryıs'kykh zapustyly audiohid ukraïns'koiu, 2021) or the POLIN Museum of the History of Polish Jews in Warsaw. ${ }^{3}$

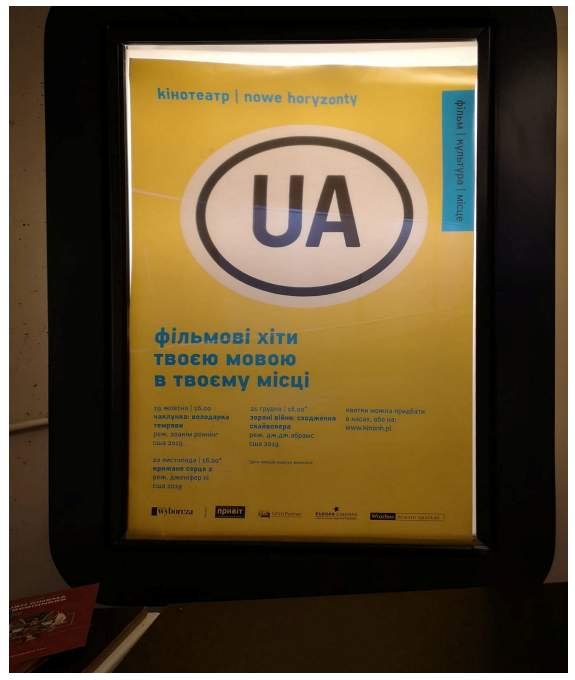

Figure 8.

\footnotetext{
3 https://www.ukrinform.ua/rubric-diaspora/3195855-u-krakivskomu-muzei-knaziv-cartorijsk ih-zapustili-audiogid-ukrainskou.html
} 


\subsection{Public Transport}

Adam Pawłowski has already focused on the possible language choices in public transport vending machines, using the example of Wroclaw (Pawłowski, 2019a, p. 178, 2019c, p. 27). Since 2019, the number of cities offering more language choices has increased. Examples from Warsaw and Wroclaw are worth mentioning, cf. Figures 9, 10.

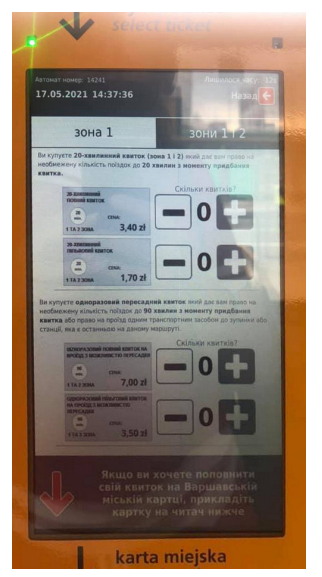

Figure 9. Photo by Vasylisa Ilishyna.

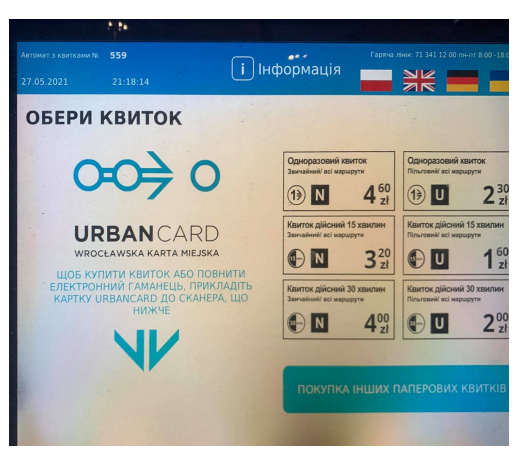

Figure 10.

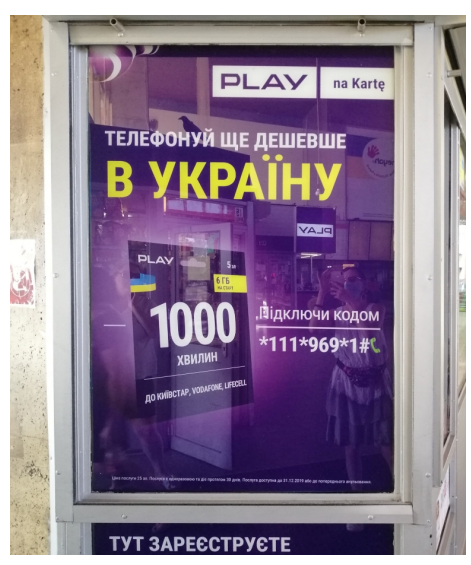

Figure 11. Photo by Olena Pelekhata.

\subsection{Mobile Operators}

Polish mobile operators have started to compete with each other intensely over Ukrainian customers in Poland. In addition to the traditional advertising on starter packs and large advertisements, you can even see Ukrainian pop stars advertising Polish mobile operators.

The Polish operator Play (cf. Figure 11) invited the famous Ukrainian band Okean Elzy (Play, 2017) to advertise in the media and another Polish operator, Plus, invited the famous Ukrainian singer Jamala (jd, 2019), who won Eurovision in 2016, to play in a promo video. Another Polish mobile operator, Heyah, offers advertising in Ukrainian between films on YouTube, cf. screenshot (Figure 12) and photo (Figure 13).

We can safely conclude that the vast majority of Polish mobile operators are actively fighting for Ukrainian customer in Poland by offering cheap calls to Ukraine and a large amount of Internet traffic at reasonable prices.

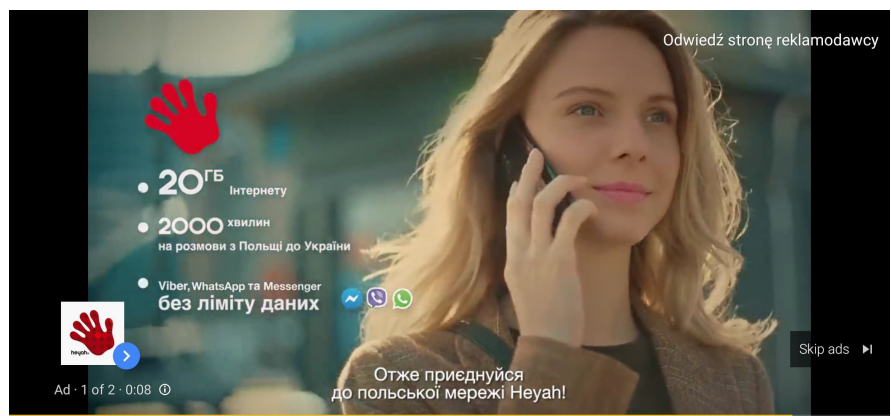

Figure 12. Photo by Anastazja Oszowska, screenshot. ${ }^{4}$

\footnotetext{
${ }^{4}$ Video: https://www. youtube. com/watch?v=EZlajbbpEWg (Heyah, 2021).
} 


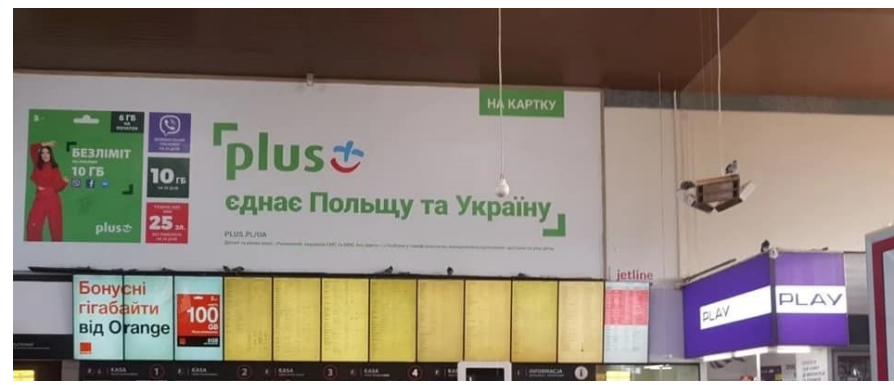

Figure 13. Photo by Anastazja Oszowska.

\subsection{Banking Institutions and Money Transfers}

The most important achievement in this area is the emergence of Ukrainian in Euronet ATMs across the country (Wojtczuk, 2019). This company has almost 8,000 ATMs across Poland, so the emergence of Ukrainian as one of the four choices of language (Polish, English, German, Ukrainian) shows a real interest in Ukrainian customers. Ukrainian is fairly well represented in the banking sector, according to the respected Polish newspaper Rzeczpospolita (Skwierawska, 2018). Banks have prepared information leaflets for potential customers in Ukrainian, in which one can find the most important information. This practice is used by PKO BP, Bank Millennium, BZ WBK, Getin Bank and BGŻ BNP Paribas, and Bank Pocztowy is considering introducing the practice. However, this service is available in large cities. Across the country, it is possible to have a telephone consultation in Ukrainian in as many as seven banks - PKO Bank Polski, Bank Zachodni WBK, Bank Pekao, Bank BGŻ BNP Paribas, Bank Millennium, Getin Bank and ING Bank Ślacski. Bank Pocztowy plans to create a Contact Center with the capability to advise clients in Ukrainian. PKO BP, Raiffeisen Polbank, Credita Agricole, Bank Pocztowy, Bank Zachodni WBK, Getin Bank and BGŻ BNP Paribas have created Ukrainian versions of their websites for Ukrainian-speaking clients. Bank Pekao has also partially prepared online private account services in Ukrainian.

Ukrainians working in Poland most often transfer money through official transfer systems. According to Narodowy Bank Polski, Ukrainians transferred 3.1 billion Polish Złoty from Poland to Ukraine in 2020 (WZI, 2021). Such a large market of transfers has led to the emergence of Ukrainian in the advertising of intermediaries, cf. Figure 14.

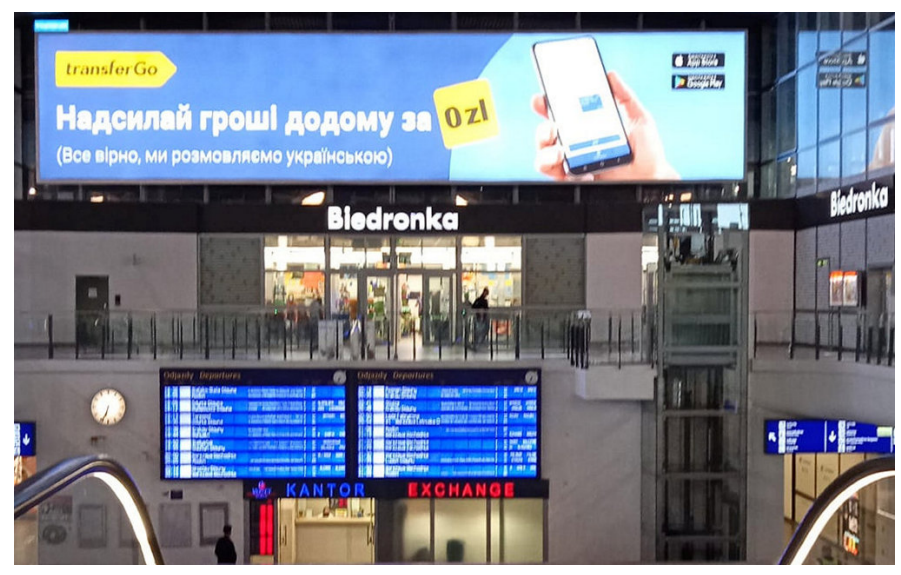

Figure $14 .{ }^{5}$

\footnotetext{
${ }^{5}$ https://www.euronetpolska.pl/p,321,_myria_i_euronet__przekaz.html\#
} 


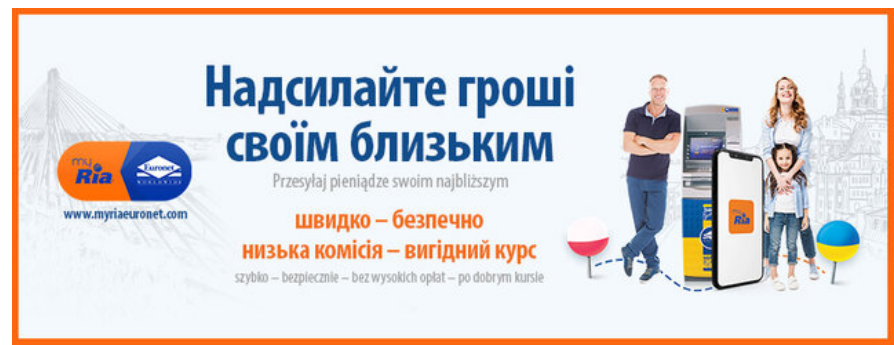

Figure 15. Photo by Iryna Kolodiychyk.

As the financial component has a great influence on the development of the language, this business sector, using Ukrainian, is developing rapidly and is becoming increasingly popular in the competition for millions of Ukrainian clients.

\subsection{Purchase of Goods and Services}

Some large networks offer a choice of Ukrainian language when ordering or at the checkout when paying for purchased goods. The two examples below are illustrated by the global fast-food chain McDonald's (cf. Figure 16) and the Polish supermarket chain Stokrotka (cf. Figure 17).

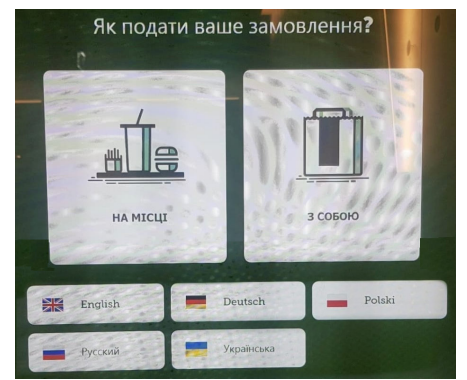

Figure 16. Photo by Oksana Fain. Figure 17. Photo by Julia Mykytiuk.

Shops selling Ukrainian products are beginning to appear in some Polish cities. An example is a chain of shops called Ukrainochka, cf. Figure 18.

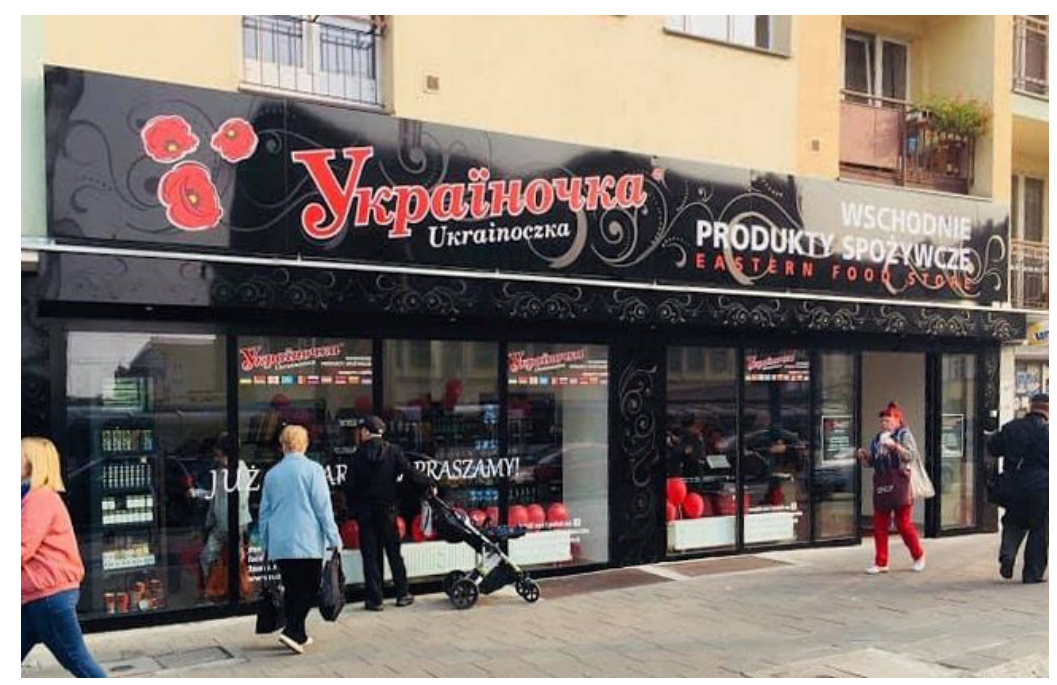

Figure 18. Photo by Olha Alex. 


\subsection{Promotion of the Ukrainian Language}

The presence of Ukrainian in Polish society is beginning to be a natural phenomenon. In Lublin, people are encouraged to learn at least a few keywords in Ukrainian that can be used daily, cf. Figure 19.

A place that for many Ukrainians has become the gateway to Poland is the Warszawa Zachodnia (Warsaw West) bus station. Signs in station are duplicated in English and Ukrainian, cf. Figure 20.

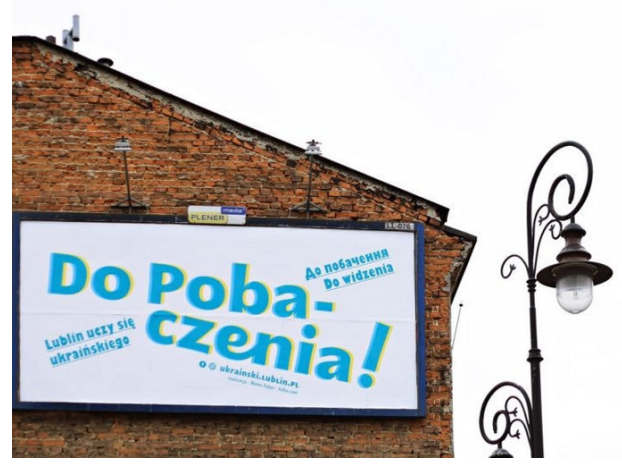

Figure 19. Photo by Irena Sudak.

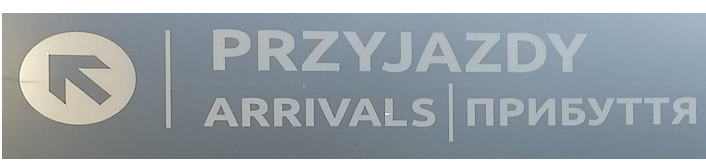

Figure 20. Photo by Anastazja Oshowska.

\subsection{Errors in Inscriptions in Ukrainian}

In spite of the desire to convey information in the language of the largest immigrant group, some business owners save time and money on checking the accuracy of even short advertisements in Ukrainian. Examples from three Polish cities: Warsaw, Przemyśl and Legnica, cf. Figure 21-23.

The text 'Dobyrannia do zupynka' was translated using an electronic translator. 'Vykhid na zupynku' (i.e. 'Access to [public transport] stop') would be a correct translation, cf. Figure 21.

Instead of the inscription 'Torhovyı avtomat pryı̆maie til'ky nastupne monety $i$, zdaiet'sia, ne na vidpochynok', it should be 'Avtomat pryimaie vykliuchno zobrazheni monety i ne vydaie reshty.' (i.e. 'This machine accepts only the depicted coins and does not give change', cf. Figure 22.

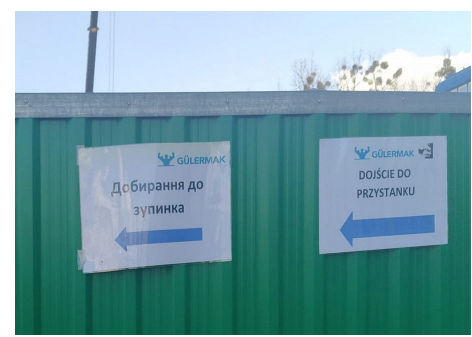

Figure 21. Photo by Lana Vasyliuk.

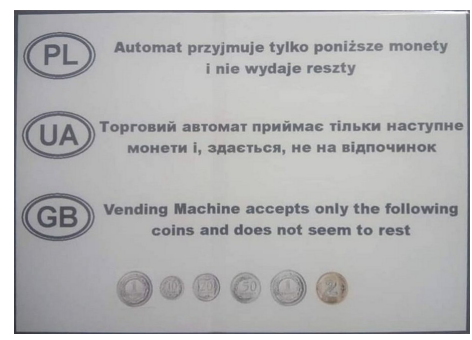

Figure 22. Photo by Anastasiia Kiezekova.

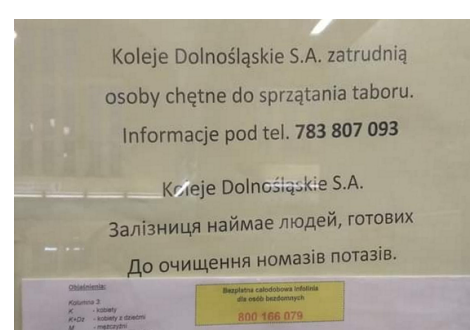

Figure 23. Photo by Georg Strabon.

In this example from the railway station of the Polish city of Legnica, it is difficult to understand the meaning without the Polish version of the text. This is another example of using translation without checking with a native speaker of Ukrainian. Many such examples can be found throughout Poland. As demonstrated in this article, three examples show from different angles that this phenomenon is present throughout the country, cf. Figure 23. 


\section{Conclusion}

The spheres in which Ukrainian is used presented in this article show only certain aspects of the phenomena, in which the presence of Ukrainian is obvious and no longer surprising. A huge number of Ukrainian-speaking employees in various fields can communicate in Ukrainian if necessary and there are many more potential places where you can hear or use Ukrainian than are mentioned in the article.

The presence of Ukrainian in Poland is directly related to the appearance of a large number of migrants who have come to work in Poland in search of a better life. Władysław Miodunka states that the social mobility of native speakers is one of the factors influencing the power of a language (Miodunka, 1990, p. 43). It is due to the presence of a large group of Ukrainians that Ukrainian has begun to appear en masse on the street, in supermarkets, on the Internet, and so on. The presence of Ukrainian is often caused by economic factors. In schools where there are foreign pupils, teachers have additional paid hours to work with them. In universities, Ukrainian students pay tuition fees. Cinemas, banks and other businesses are all striving to serve and profit from Ukrainian customers.

The strong position of Ukrainian in Polish public space is beginning to arouse the interest of Polish linguistics, as Stanisław Dubisz writes very cautiously (Dubisz, 2020, p. 120). No other language, except global English, has been able to gain such a position in Polish society in such a short space of time as Ukrainian. The status and functioning of the Ukrainian language in Poland should be the subject of separate linguistic research.

\section{References}

Backhaus, P. (2007). Linguistic landscapes: A comparative study of urban multilingualism in Tokyo. Multilingual Matters. https://doi.org/10.21832/9781853599484

Berehsasi, A., Hazdah, V., \& Chernychko, I. (2020). Movna polityka ta movnyŭ landshaft: Pol's'ka mova na banknotakh Chekhoslovats'koï Respubliky 1919-1938. Ukraïns'ka polonistyka, 18, 13-29. https : //doi.org/10.35433/2220-4555.18.2020.fil-2

Bever, O. A. (2010). Linguistic landscapes of post-Soviet Ukraine: Multilingualism and language policy in outdoor media and advertising [Doctoral dissertation, University of Arizona]. ProQuest. https: //search.proquest. com/openview/afa0455592c068590c68ad6b88634aed/1?pqorigsite=gscholar $\& \mathrm{cbl}=18750 \&$ diss $=\mathrm{y}$

Demska, O. (2019). Hybridity and the linguistic landscape. Cognitive Studies / Études cognitives, 2019(19), Article 2007. https://doi.org/10.11649/cs. 2007

Demska, O., \& Levchuk, P. (2020). The urbanonimia of Ukraine in the context of decommunization. Cognitive Studies / Études cognitives, 2020(20), Article 2280. https://doi.org/10.11649/cs.2280

Dubisz, S. (2020). Polityka językowa. Poradnik Jezykowy, 2020(9), 118-120. https://doi.org/10.33896 /PorJ .2020.9.9

Gorter, D. (2006). Introduction: The study of the linguistic landscape as a new approach to multilingualism. In D. Gorter (Ed.), Linguistic landscape: A new approach to multilingualism (pp. 1-6). Multilingual Matters. https://doi.org/10.21832/9781853599170-001

Gorter, D. (2013). Linguistic landscapes in a multilingual world. Annual Review of Applied Linguistics, 33, 190-212. https://doi.org/10.1017/S0267190513000020

Heyah. (2021, June 2). Heyah: Na dobryı̆ pochatok 35zl na 30 dniv! [Video]. YouTube. https://www . yout ube.com/watch?v=EZlajbbpEWg

jd. (2019, March 19). Jamala w kampanii Plusa promujacej ofertę dla Ukraińców. Wirtualnemedia.pl. https://www.wirtualnemedia.pl/artykul/jamala-oferta-dla-ukraincow-plus

Krasowska, H. (2020). Języki mniejszości: Status, prestiż, dwujęzyczność, wielojęzyczność. Studium Europy Wschodniej UW.

Laihonen, P. (2015). Linguistic landscapes of a minoritized regional majority: Language ideologies among Hungarians in South-West Slovakia. In M. Laitinen \& A. Zabrodskaja (Eds.), Dimensions of sociolinguistic landscapes in Europe: Materials and methodological solutions (pp. 171-198). Peter Lang. 
Levchuk, P. (2019). Ukrainian, Polish and Russian trilingualism among Ukrainians of non-Polish origin living in Poland. Cognitive Studies / Études cognitives, 2019(19), Article 1988. https://doi.org/10 $.11649 / \mathrm{cs} .1988$

Levchuk, P. (2020). Trójjęzyczność ukraińsko-rosyjsko-polska Ukraińców niepolskiego pochodzenia. Księgarnia Akademicka. https://doi.org/10.12797/9788381382854

Miodunka, W. (1990). Moc języka i jej znaczenie w kontaktach językowych i kulturowych. In W. Miodunka (Ed.), Język polski w świecie (pp. 39-50). Państwowe Wydawnictwo Naukowe.

Miodunka, W. (2016). Glottodydaktyka polonistyczna: Pochodzenie - stan obecny-perspektywy. Księgarnia Akademicka.

Pavlenko, A. (2009). Language conflict in post-Soviet linguistic landscapes. Journal of Slavic Linguistics, 17(1-2), 247-274. https://doi.org/10.1353/jsl.0.0025

Pavlenko, A. (2010). Linguistic landscape of Kyiv, Ukraine: A diachronic study. In E. Shohamy, E. BenRafael, \& M. Barni (Eds.), Linguistic landscape in the city (pp. 133-150). Multilingual Matters. https://doi.org/10.21832/9781847692993-010

Pawłowska, M. (2018). Enseignement de la littérature française ancienne: Souvenirs et témoignage. Romanica Wratislaviensia, 65, 107-117.

Pawłowski, A. (2019a). The linguistic landscape of modern Poland. In T. Schoonheim \& J. Van Hoorde (Eds.), Language variation: A factor of increasing complexity and a challenge for language policy within Europe: Contributions to the EFNIL Conference 2018 in Amsterdam (pp. 159-183). Research Institute for Linguistics, Hungarian Academy of Sciences.

Pawłowski, A. (2019b). Pejzaż językowy Polski współczesnej: Polszczyzna, języki obce, języki mniejszościowe. Poradnik Jezykowy, 2019(8), 7-27.

Pawłowski, A. (2019c). Pejzaż językowy Polski współczesnej: Powrót do przyszłości? Poradnik Językowy, 2019(10), 19-34. https://doi.org/10.33896/PorJ .2019.10.2

Play. (2017, January 27). Play na Karte / Najtańsze połaczenia z Polski na Ukraine / Naŭdeshevshi dzvinky z Pol'shchi $v$ Ukraïnu [Video]. YouTube. https://www . youtube.com/watch?v=zy-uQCa-FaY\&t=2s

Redkva, M. (2020). Status ukraïns'koï movy v konteksti bahatomovnosti. Studia Ukrainica Posnaniensia, 8(1), 147-155. https://doi.org/10.14746/sup.2020.8.1.15

Shohamy, E. (2012). Linguistic landscapes and multilingualism. In M. Martin-Jones, A. Blackledge, \& A. Creese (Eds.), The Routledge handbook of multilingualism (pp. 538-551). Routledge.

Shohamy, E., \& Gorter, D. (2009). Introduction. In E. Shohamy \& D. Gorter (Eds.), Linguistic landscape: Expanding the scenery (pp. 1-10). Routledge.

Shohamy, E., \& Waksman, S. (2009). Linguistic landscape as an ecological arena: Modalities, meanings, negotiations, education. In E. Shohamy \& D. Gorter (Eds.), Linguistic landscape: Expanding the scenery (pp. 313-331). Routledge.

Skwierawska, N. (2018, February 10). Banki z obstuga w języku ukraińskim. Rzeczpospolita.pl. https: //www.rp.pl/Banki/302109983-Banki-z-obsluga-w-jezyku-ukrainskim.html

U Krakivs'komu muzeї kniaziv Chartoryı̌s'kykh zapustyly audiohid ukraïns'koiu. (2021, February 24). Nash vybir - informatsiünyı̆ portal dlia ukraïntsiv u Pol'shchi. https://naszwybir.pl/u-krakivskomu-muz eyi-knyaziv-chartoryjskyh-zapustyly-audiogid-ukrayinskoyu/

Wojtczuk, M. (2019, February 28). Sieć bankomatów wprowadza obsługę w języku ukraińskim. Gazeta.pl. https://warszawa.wyborcza.pl/warszawa/7,54420,24503303,siec-bankomatow-wprowadza-obslug e-w-jezyku-ukrainskim.html

Wróblewska-Pawlak, K., \& Strachanowska, I. (2000). Preferencje językowe młodzieży polskiej w okresie transformacji 1990-1999. Studia Europejskie, 2000(1), 99-114. https://www.ce.uw.edu.pl/pliki/p w/1-2000_Wroblewska-Pawlak.pdf

WZI. (2021, February 8). Ukraińcy masowo wysylaja pieniadze do kraju: Ponad 80 proc. przekazów. money.pl. https://www.money.pl/pieniadze/ukraincy-masowo-wysylaja-pieniadze-do-kraju-p onad-80-proc-przekazow-6606074258442944a.html

\footnotetext{
This article was financed by the Polish Ministry of Education and Science.

This article was supported by the CLARIN-PL (http://clarin-pl.eu) research infrastructure.

Competing interests: The author is the Editorial Secretary of the journal.
} 
a This is an Open Access article distributed under the terms of the Creative Commons Attribution 3.0 PL License (http://creativecommons.org/licenses/by/3.0/pl/), which permits redistribution, commercial and non-commercial, provided that the article is properly cited.

\section{(C) The Author 2021}

Publisher: Institute of Slavic Studies, Polish Academy of Sciences

Publishing history: Received 2020-12-27; Accepted 2021-07-13; Published 2021-10-11. 